\title{
Analysis of Some Computer Codes Used for Evaluation of Spent Nuclear Fuel Radiation Parameters
}

\author{
- Smaizys A. \\ Lithuanian Energy Institute, Kaunas, Lithuania \\ ORCID: https://orcid.org/0000-0003-0384-3022 \\ - Narkunas E. \\ Lithuanian Energy Institute, Kaunas, Lithuania \\ ORCID: https://orcid.org/0000-0002-6734-9966 \\ - Rudychev V. \\ V.N. Karazin Kharkiv National University, Kharkiv, Ukraine \\ ORCID: https://orcid.org/0000-0002-7749-7858 \\ - Rudychev Y. \\ V.N. Karazin Kharkiv National University, Kharkiv, Ukraine \\ NSC "Kharkov Institute of Physics and Technology", Kharkiv Ukraine \\ ORCID: https://orcid.org/0000-0002-1453-2062
}

\begin{abstract}
The radiation parameters such as radionuclide content and activities, fluxes and energy spectrum of gamma and neutrons of spent nuclear fuel are essential when planning further spent fuel management options - interim wet or dry storage or disposal into a geological repository. Radiation parameters determine the design of a storage or disposal facility, what materials, structures and thicknesses of structures should be used to provide adequate biological shielding.

Experimental measurements of spent fuel radiation parameters are rather complicated and expensive, therefore numerical methods are widely used. Various computer codes (APOLLO, BOXER, CASMO, FISPACT, ORIGEN-S, WIMS, etc.) have been developed to simulate the irradiation processes of nuclear fuel and to obtain resulting radiation parameters. Irrespective of the used computer code, the input data firstly must be entered into that code. When simulating nuclear fuel irradiation and burn-up in the reactor core, the geometrical parameters of the fuel assembly, materials' data (chemical compositions, densities), the operating parameters of the reactor (power, operation time, coolant parameters, etc.) shall be entered into the program as initial data. Fairly often approximations of the input data are performed, for example, fuel rods in a fuel assembly are homogenized and geometrically described as a solid cylinder, the reactor operation time is assumed as continuous and at constant power. The particularity of the input data and accepted assumptions depend on what initial information is available and on the capabilities of the computer code. The modelled spent fuel radiation parameters depend not only on the input data and assumptions, but also on the cross-section databases that are used in computer codes. Computer codes TRITON, ORIGEN-S and FISPACT have been used to model the concentration of actinides and fission products in the spent fuel from the RBMK-1000 reactor. The obtained results are compared and possible reasons for the differences in the modelling results are discussed.
\end{abstract}

Ke y w o r ds: spent nuclear fuel, nuclide composition, container, radiation safety, mathematical modelling.

() Smaizys A., Narkunas E., Rudychev V., Rudychev Y., 2019

$\mathrm{T}$

The radiation parameters such as radionuclide content and activities, fluxes and energy spectrum of gamma and neutrons of spent nuclear fuel are important when planning further SNF management options, for instance, interim wet or dry storage or disposal into a repository. Radiation parameters determine the design of a storage or disposal facility and what materials, structures and thicknesses of structures should be used to provide adequate biological shielding. Also, knowledge of the radiation parameters is necessary when assessing long-term effects on the structures and materials of the storage or disposal container. Experimental measurements of SNF radiation parameters are rather complicated and expensive and therefore numerical methods are widely used. Various 
computer codes (APOLLO, BOXER, CASMO, FISPACT, ORIGEN-S, WIMS, etc.) have been developed to simulate the irradiation processes of nuclear fuel and to obtain resulting radiation parameters. Irrespective of the used computer code, the input data firstly must be entered into that code. When simulating nuclear fuel irradiation and burn-up in the reactor core, the geometrical parameters of the fuel assembly, materials' data (chemical compositions, densities) and the operating parameters of the reactor (power, operation time, coolant parameters, etc.) shall be entered into the program as initial data. Fairly often approximations of the input data are performed, for example, fuel rods in a fuel assembly are homogenized and geometrically described as a solid cylinder, the reactor operation time is assumed as continuous and at constant power. The particularity of the input data and accepted assumptions depend on what initial information is available and on the capabilities of the computer code. The modelled SNF radiation parameters depend not only on the input data and assumptions, but also on the cross-section databases that are used in computer codes.

\section{Problem definition}

After the permanent shutdowns of the Chernobyl NPP (Ukraine) and the Ignalina NPP (Lithuania) with RBMK type power reactors, numerous amounts of spent fuel assemblies need to be further managed. A dry storage facility currently is the most efficient way for spent fuel interim storage for at least 50 years. In evaluating the safety of the spent fuel storage facility, one of the most essential tasks is the determination of the SNF radiation parameters. Subsequently, these parameters are used in shielding analysis, source term estimation or in the criticality safety analysis if burn-up credit is applied.

Accuracy of determining the radiation parameters depends on computer codes used and on what assumptions and approximations were made describing the numerical model. Computer codes TRITON, ORIGEN-S and FISPACT have been used to model the concentration of actinides and fission products in the spent fuel from the RBMK-1000 reactor.

\section{Methodology}

The computer code TRITON is the module of the SCALE system, which performs transport, depletion, sensitivity and uncertainty analysis for $1 \mathrm{D}, 2 \mathrm{D}$, and $3 \mathrm{D}$ configurations of complex fuel assemblies and other nuclear systems. FISCPACT is a computer code that performs modelling of activation, transmutations and depletion induced by neutron, proton, alpha, deuteron or gamma particles interaction with matter. Also ORIGEN-S was used as a standalone code to calculate time-dependent isotopes concentrations and activities generated or depleted by fission and radioactive decay.

The main problem that all mentioned computer codes solve is the time rate of the concentration change of certain nuclide $N_{i}$. In general, the rates of three processes determine the concentration change of nuclide $N_{i}$ :

$$
\frac{d N_{i}}{d t}=\text { Formation }- \text { Destruction }- \text { Decay }
$$

More detailed expression of the mentioned processes can be written as follows:

$$
\begin{gathered}
\frac{d N_{i}}{d t}=\sum_{j} \gamma_{j i} \sigma_{f, j} N_{j} \phi+\sigma_{c, i-1} N_{i-1} \phi+ \\
+\lambda_{i}^{\prime} N_{i}^{\prime}-\sigma_{f, i} N_{i} \phi-\sigma_{c, i} N_{i} \phi-\lambda_{i} N_{i}
\end{gathered}
$$

where: $\Sigma_{j} \gamma_{j i} \sigma_{f, j} N_{j} \phi$ is the yield of $N_{i}$ due to the fission of all nuclides $N_{j}$; is $\sigma_{c, i-1} N_{i-1} \phi$ is transmutation into $N_{i}$ due to neutron capture by nuclide $N_{i-1} ; \lambda_{i}{ }^{\prime} N_{i}{ }^{\prime}-$ is the formation of $N_{i}$ due to the radioactive decay of nuclide $N_{i}$; $\sigma_{f, i} N_{i} \phi$ is the destruction of $N_{i}$ due to fission; $\sigma_{c, i} N_{i} \phi$ is the destruction rate of $N_{i}$ due to all forms of neutron capture $(n, \gamma),(n, \alpha),(n, p)$, $(n, 2 n)(n, 3 n) ; \lambda_{i} N_{i}$ is the radioactive decay rate of $N_{i}$.

Based on the previous modelling methods ofRBMK-1500spentfuel radiation characteristics $[1,2]$, the RBMK-1000 fuel assembly inside the reactor's fuel channel surrounded with coolant and the channel surrounded with graphite blocks was described as a $2 \mathrm{D}$ model in the TRITON code (figure 1). The RBMK-1000 fuel of initial $2.0 \%$ U-235 enrichment was 


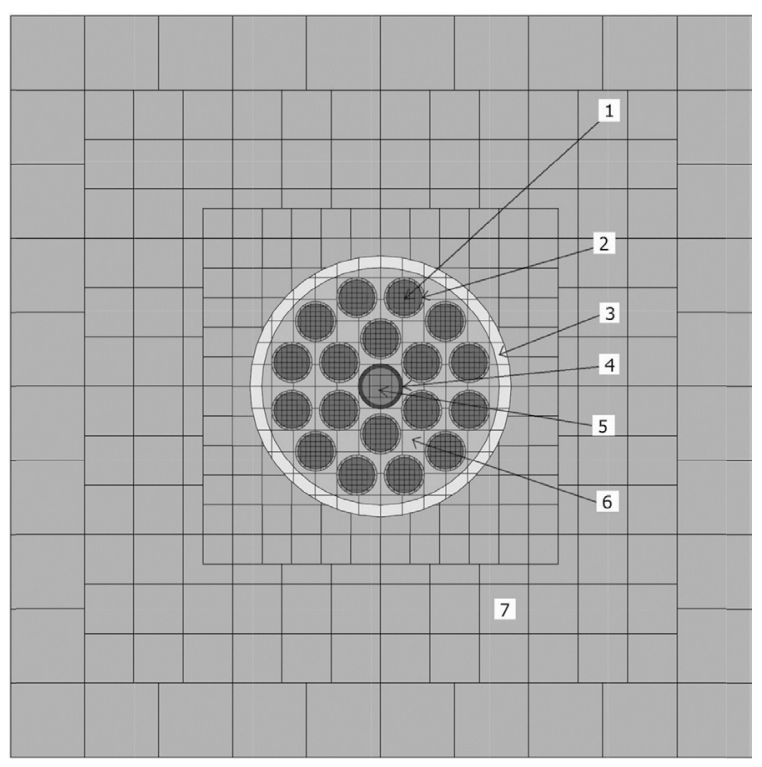

Figure $1-$ RBMK fuel assembly inside the fuel channel ( 1 - fuel pellet; 2 - fuel rod cladding; 3 - central FA tube; $4-$ channel tube; $5-$ void; $6-$ coolant)

accepted in the calculations. It was assumed that at constant specific reactor power the burnup of the fuel varies from 1 to $20 \mathrm{MWd} / \mathrm{kgU}$, the burn-up profile of FA in the $\mathrm{z}$-axis is uniform, and the average coolant density is $0.43 \mathrm{~g} / \mathrm{cm}^{3}$. Additionally, influence of the neutron spectrum on the nuclide concentration variation with burn-up thermal and total neutron fluxes with corresponding normalization of energy groups was analysed in the ORIGEN-S and FISPACT models.

The TRITON code performs neutron transport modelling and therefore, while modelling the fuel depletion process, automatically takes into account the build-up of various actinides and fission products due to the fuel burn-up and the corresponding changes of neutron fluxes and energy spectrums, time-dependent cross-section libraries are produced.

Although FISPACT is able to calculate irradiation effects for a wide range of actinides, the code was developed mainly for irradiation modelling of materials with natural actinide content ( $\mathrm{U}$ and $\mathrm{Th}$ ). EAF activation libraries that are used in the FISPACT code contain cross-sections for infinitive medium (infinitely dilute cross sections) and therefore, if actinides constitute a significant part of the initial input data, the results will not be representative, since the effects of the neutron spectrum change due to attenuation and self-shielding during the fuel burn-up are not taken into account. Therefore, when simulating the irradiation of actinides or nuclear fuel, the FISPACT results will not be as accurate as those of specific computer codes developed for reactor depletion calculations. The developers of the FISPACT code warn that if the data on the neutron spectrum is not comprehensive enough, the FISPACT code with EAF libraries will give approximate results when irradiation modelling is performed for a large amount of actinides. In addition, the FISPACT code does not take into account the geometry of materials in the modelling. In terms of input data and modelling capabilities the ORIGEN-S as a standalone code is rather similar to the FISPACT. Therefore, the same input information on neutron spectrums and fluxes was used for FISPACT and ORIGEN-S codes.

\section{Discussion of results}

Modelling results of U-235, $\mathrm{Pu}-239, \mathrm{Pu}-242, \mathrm{Cm}-$ $242, \mathrm{Cm}-244$ and Cs-137 concentration variation with fuel burn-up are presented in figure 2-7. Since the aim of performed analysis was to compare the results obtained with different computer codes, therefore, calculated concentrations only of some isotopes are presented below.

The smallest difference in fuel burn-up modelling results obtained by different codes is for U-235 concentration. For other isotopes that were considered, calculated concentrations with the ORIGEN-S and FISPACT are overestimated in comparison with the values obtained with TRITON code. The main reason of the TRITON, ORIGEN-S and FISPACT simulation result differences is that while the fuel burn-up is increasing, the buildup of actinides and fission products in the fuel occurs, and this process influences the neutron fluxes and their energy spectrums. This process in the TRITON code is taken into account by specifying a certain number of burn-up steps. The nuclide composition and concentrations of the previous step is accepted as the initial material input data for the next step, also time-dependent cross-section libraries are produced to reflect fuel composition variations during irradiation.

Further analysing the influence of the neutron spectrum on the nuclide concentration variation 


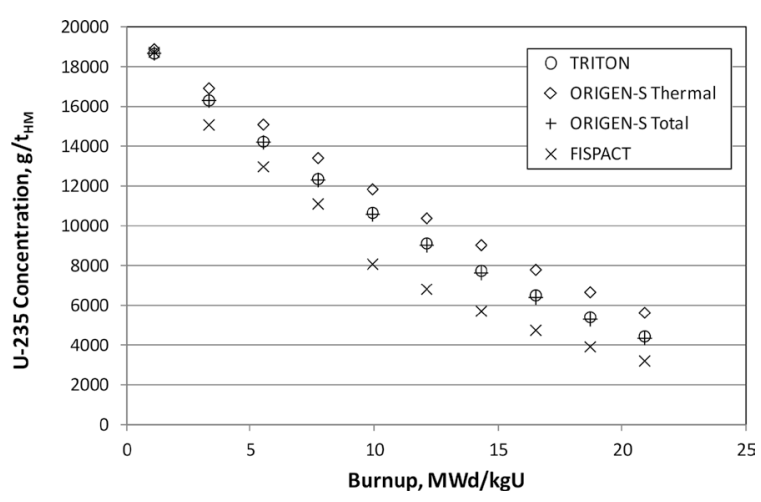

Figure $2-\mathrm{U}-235$ concentration variation with burn-up

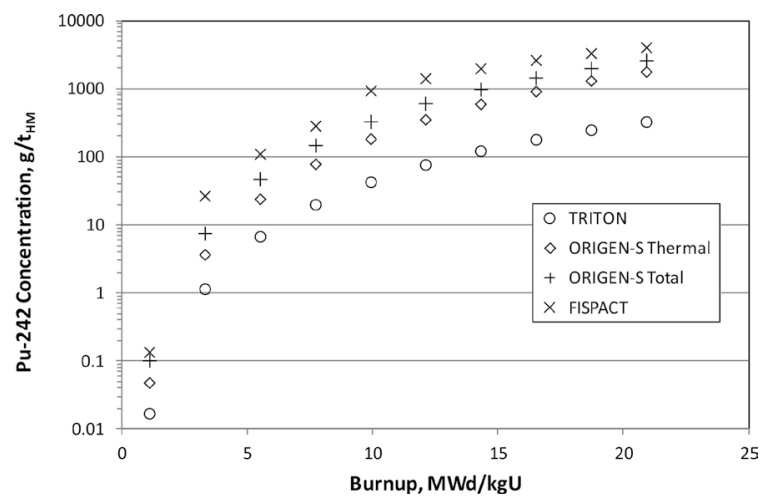

Figure $4-\mathrm{Pu}-242$ concentration variation with burn-up

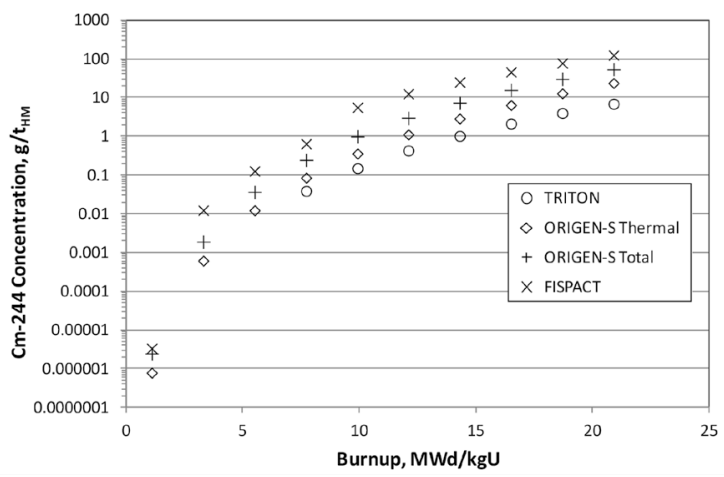

Figure $6-\mathrm{Cm}-244$ concentration variation with burn-up

with burn-up, the FISPACT modelling has been performed for the following two cases:

- Case 1: assuming the average spectrum for thermal neutron flux and spectrum of other energies;

- Case 2: assuming the total neutron flux and spectrum.

The FISPACT modelling results (see tables 1-3) are compared with the data presented in [3]. The [3] report contains comparison between experimentally measured isotope concentrations of the RBMK-1000 fuel samples with different burn-ups and the modelling results performed also

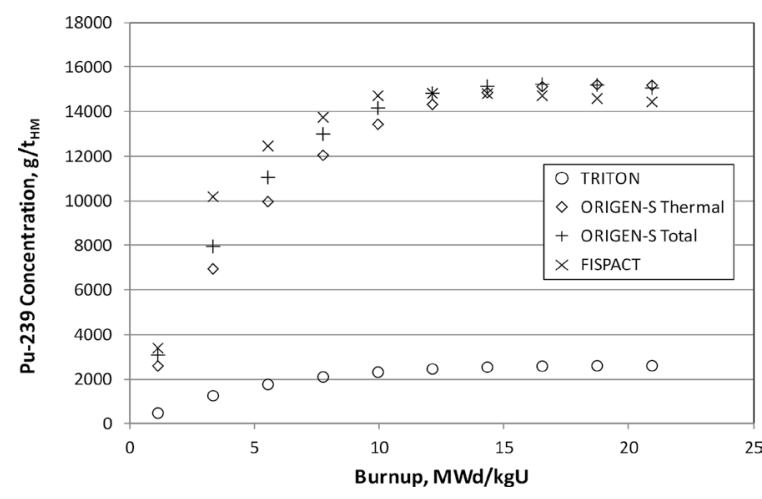

Figure $3-\mathrm{Pu}-239$ concentration variation with burn-up

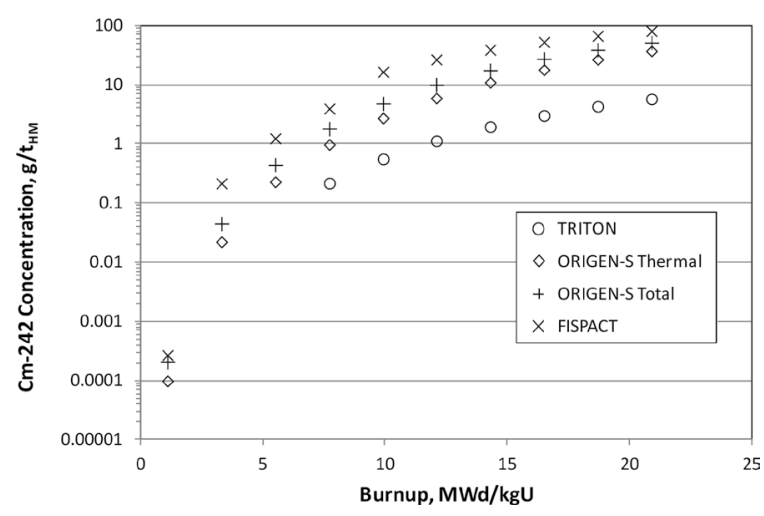

Figure $5-\mathrm{Cm}-242$ concentration variation with burn-up

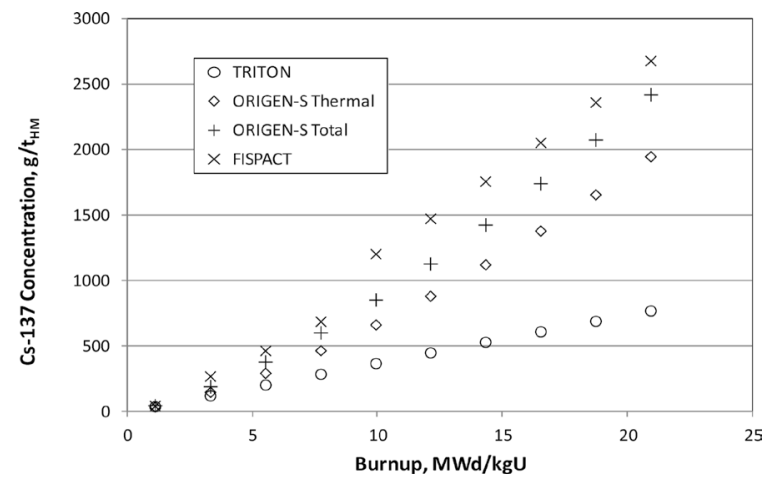

Figure 7 - Cs-137 concentration variation with burn-up

with the TRITON computer code. Also the similar comparison but using modules TRITON/T6DEPL and ORIGEN-ARP of computer code system SCALE 6 was presented in [4].

The performed comparative analysis of the results obtained with different computer codes and available experimental measurements of RBMK fuel samples confirms the earlier assumption that in order to perform accurate simulation of irradiated fuel characteristics, it is necessary to know neutron fluxes and energy spectrums during the fuel burn-up. Otherwise, only a qualitative assessment of irradiate nuclear 
Table 1. Comparison of measured and modelled concentrations (values are grams per U-238 gram) for a sample with burn-up $6.96 \mathrm{GWd} / \mathrm{tU}$

\begin{tabular}{|c|c|c|c|c|}
\cline { 2 - 5 } \multicolumn{1}{c|}{} & Measured [3] & TRITON [3] & FISPACT (Case 1) & FISPACT (Case 2) \\
\hline $\mathrm{U}-235$ & $1.41 \times 10^{-2}$ & $1.39 \times 10^{-2}$ & $1.30 \times 10^{-2}$ & $5.07 \times 10^{-3}$ \\
\hline $\mathrm{Cm}-244$ & $4.30 \times 10^{-8}$ & $1.88 \times 10^{-8}$ & $1.27 \times 10^{-9}$ & $1.43 \times 10^{-8}$ \\
\hline $\mathrm{Pu}-239$ & $1.65 \times 10^{-3}$ & $1.96 \times 10^{-3}$ & $7.73 \times 10^{-4}$ & $1.67 \times 10^{-3}$ \\
\hline $\mathrm{Cs}-137$ & $2.45 \times 10^{-4}$ & $2.48 \times 10^{-4}$ & $2.28 \times 10^{-4}$ & $5.53 \times 10^{-4}$ \\
\hline
\end{tabular}

Table 2. Comparison of measured and modelled concentrations (values are grams per U-238 gram) for a sample with burn-up $11.56 \mathrm{GWd} / \mathrm{tU}$

\begin{tabular}{|c|c|c|c|c|}
\cline { 2 - 5 } \multicolumn{1}{c|}{} & Measured [3] & TRITON [3] & FISPACT (Case 1) & FISPACT (Case 2) \\
\hline $\mathrm{U}-235$ & $7.47 \times 10^{-3}$ & $7.74 \times 10^{-3}$ & $4.38 \times 10^{-3}$ & $1.37 \times 10^{-4}$ \\
\hline $\mathrm{Cm}-244$ & $6.16 \times 10^{-7}$ & $4.33 \times 10^{-7}$ & $3.54 \times 10^{-7}$ & $4.90 \times 10^{-6}$ \\
\hline $\mathrm{Pu}-239$ & $2.40 \times 10^{-3}$ & $2.50 \times 10^{-3}$ & $1.22 \times 10^{-3}$ & $1.71 \times 10^{-3}$ \\
\hline $\mathrm{Cs}-137$ & $8.50 \times 10^{-4}$ & $8.48 \times 10^{-4}$ & $5.98 \times 10^{-4}$ & $1.06 \times 10^{-3}$ \\
\hline
\end{tabular}

Table 3. Comparison of measured and modelled concentrations (values are grams per U-238 gram) for a sample with burn-up 23.47 GWd/tU

\begin{tabular}{|c|c|c|c|c|}
\cline { 2 - 5 } \multicolumn{1}{c|}{} & Measured [3] & TRITON [3] & FISPACT (Case 1) & FISPACT (Case 2) \\
\hline $\mathrm{U}-235$ & $2.89 \times 10^{-3}$ & $3.07 \times 10^{-3}$ & $1.19 \times 10^{-3}$ & $2.49 \times 10^{-6}$ \\
\hline $\mathrm{Cm}-244$ & $9.44 \times 10^{-6}$ & $1.02 \times 10^{-5}$ & $3.24 \times 10^{-6}$ & $4.74 \times 10^{-5}$ \\
\hline $\mathrm{Pu}-239$ & $2.52 \times 10^{-3}$ & $2.55 \times 10^{-3}$ & $1.28 \times 10^{-3}$ & $1.69 \times 10^{-3}$ \\
\hline $\mathrm{Cs}-137$ & $9.42 \times 10^{-4}$ & $9.18 \times 10^{-4}$ & $8.32 \times 10^{-4}$ & $1.62 \times 10^{-3}$ \\
\hline
\end{tabular}

fuel nuclide composition and concentrations is possible. The most subtle difference between the modelled results is for the fission products, since their concentrations mainly depend on the decay reaction, which does not depend on the neutron flux and spectrum. The difference in the actinides production increases not linearly with the irradiation time and the burn-up due to the cross section resonances and a large number of the generated daughter isotopes, which are not considered correctly in the FISPACT. A good convergence of the results is obtained when simulating the neutron transport by the Monte Carlo method at different irradiation steps, where the effects of material compositions, the neutron flux and other changes are automatically taken into account by the code. However, although these effects are considered, the different computer codes will provide different results due to their model description peculiarities, used cross-section libraries and numerical methods. For instance, the same model of PWR fuel assembly was described in APOLLO2, KORIGEN, and ORIGEN2 codes and irradiation simulation was performed [5]. The obtained concentration values with various codes for $\mathrm{U}$ and $\mathrm{Pu}$ isotopes was different by $10 \%$, for Am isotopes - $20 \%$, for Cm-242, Cm-244 $25 \%$, and for Cm-245, Cm-246 - $70 \%$.

\section{Conclusions}

1. In order to perform accurate spent fuel irradiation modelling and to obtain representative results for the FISPACT and ORIGEN-S codes, the neutron flux and the spectrum and their variations during the irradiation must be considered. 
2. Numerical modelling must also take into account the build-up of various actinides and fission products in the irradiated fuel, since these products change the neutron fluxes and the energy spectrums.

3. RBMK irradiation modelling using TRITON can be more precise if the burn-up profile of a fuel assembly is considered.

\section{Acknowledgments}

Results were obtained and publication is prepared in frame of the Lithuanian-Ukrainian Cooperation Programmein theFields of Research and Technologies according to Research Council of Lithuania (research contract No. S-LU-18-5) and Ukrainian State Science, Innovation and Information Agency (research contract No.M/81) R\&D project "Comparative analysis of the modelling methodologies and results for evaluation of the RBMK-1000 (Ukraine) and RBMK-1500 (Lithuania) spent nuclear fuel's radiation/ thermal parameters in dry storage conditions".

\section{圓 References}

1. Šmaižys, A., Poškas, P. (2001). Analysis of radiation characteristics for casks loaded with spent RBMK-1500 nuclear fuel. Proceedings of International Conference Nuclear Energy in Central Europe 2001. Slovenia, 2001.

2. Šmaižys, A., Poškas, P., Narkūnas, E., Bartkus, G. (2017). Numerical modelling of radionuclide inventory for RBMK irradiated nuclear fuel. Nuclear Engineering and Design, V. 277, 28-35.

3. Murphy, B. (2006). ORIGEN-ARP cross-section libraries for the RBMK-1000 system. Report ORNL/ TM-2006/139, Oak Ridge National Laboratory, 139 p.

4. Soloviov, V., Lebedev, E. (2013). Calculations of the nuclide composition of spent nuclear fuel RBMK-1000 for verification computer module SCALE-6. Nuclear Physics and Atomic Energy, V. 14, № 4, 367-371.

5. Magill, J., Berthou, V., Hass, D., Galy, J., Shenkel, R., Wiese, H.-W., Heusener, G., Tommasi, J., Youinou, G. (2003). Impact limits of partitioning and transmutation scenarios on the radiotoxicity of actinides in radioactive waste. Nuclear Energy, V. 42, № 5, 263-277.

\section{Анализ некоторых программ, используемых для оценки радиационных параметров отра- ботанного ядерного топлива}

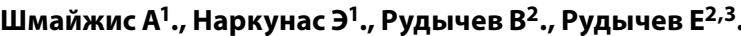 \\ ${ }^{1}$ Литовский институт энергетики, Каунас, Литва \\ ${ }^{2}$ Харьковский начиональный университет им. В.Н. Кара- \\ зина, Харьков, Украина \\ ${ }^{3}$ ННЦ «Харьковский физико-технический институт», \\ Харьков, Украина
}

Радиачионные параметры отработанного ядерного топлива, такие как радионуклидный состав и активность, потоки и энергетические спектры гамма квантов и нейтронов, являются существенными при планировании дальнейших шагов обращения с отработавшим топливом - временного мокрого или сухого хранения или помещения вгеологический могильник. Радиационные параметры определяют конструктивные решения при проектировании хранилища или могильника, какие материалы, толщины конструкций следует использовать для обеспечения биологической защиты.

Экспериментальные измерения радиачионных параметров отработанного топлива являются довольно сложными и дорогими, поэтому широко используются численные методы. Разработаны различные компьютерные программы (APOLLO, BOXER, CASMO, FISPACT, ORIGEN-S, WIMS и др.) для моделирования прочессов облучения ядерного топлива и получения радиачионных параметров. Независимо от используемой компьютерной программы, сначала необходимо ввести входные данные. При моделировании облучения и выгорания ядерного топлива в активной зоне реактора, геометрические параметры тепловыделяющей сборки, данные материалов (химический состав, плотность), рабочие параметры реактора (мощность, время работы, параметры теплоносителя и т. д.) должны быть введены в программу как исходные данные. Достаточно часто выполняется аппроксимачия входных данных, например, тепловыделяющие элементы в сборке гомогенизируются и геометрически описываются как сплошной чилиндр, время работы реактора предполагается непрерывным при постоянной мощности. Тщательность входных данных и сделанные допущения зависят от того, какая исходная информачия доступна и от возможностей компьютерной программы. Смоделированные радиационные параметры отработанного топлива зависят не только от исходных данных и допущений, но также от баз данных сечения, которые используются в компьютерных программах. Компьютерные программы TRITON, ORIGEN-S и FISPACT использовались для моделирования концентрации актинидов и продуктов деления в отработанном топливе реактора РБМК-1000. Полученные результаты сравниваются и обсуждаются возможные причины расхождений в результатах моделирования.

Ключевые слова: отработанное ядерное mоnливо, изотопный состав, контейнер, радиационная безопасность, математическое моделирование. 
Аналіз деяких програм, використовуваних для оцінки радіаційних параметрів відпрацьованого ядерного палива

Шмайжис $A^{1}$., Наркунас $E^{1}$., Рудичев $B^{2}$., Рудичев $\epsilon^{2,3}$. 1 Литовський інститут енергетики, Каунас, Литва

${ }^{2}$ Харківський національний університет ім. В. Н. Каразіна, Харків, Україна

${ }^{3}$ ННЦ «Харківський фізико-технічний інститут» Харків Україна

Радіаційні параметри відпрацьованого ядерного палива, такі як радіонуклідний склад та активність, потоки та енергетичні спектри гамма квантів і нейтронів, $\epsilon$ суттєвими при плануванні подальших кроків поводження з відпрацьованим паливом - тимчасового мокрого чи сухого зберігання або поміщення до геологічного могильнику. Радіаційні параметри, при проектуванні сховища або могильника, визначають конструктивні рішення, які матеріали, товщини конструкцій потрібно використовувати для забезпечення біологічного захисту.

Експериментальні вимірювання радіачійних параметрів відпрацьованого палива $\epsilon$ досить складними і коштовними, тому широко використовуються чисельні методи. Розроблено різні комп'ютерні програми (APOLLO, BOXER, CASMO, FISPACT, ORIGEN-S, WIMS i ін.) Для моделювання прочесів опромінення ядерного палива та отримання радіаційних параметрів. Незалежно від використовуваної комп'ютерної програми, спочатку необхідно ввести вхідні дані. При моделюванні опромінення і вигорання ядерного палива в активній зоні реактора, геометричні параметри тепловиділяючої збірки, дані матеріалів (хімічний склад, щільність), робочі параметри реактора (потужність, час роботи, параметри теплоносія та ін.) Повинні бути введені в програму як вихідні дані. Досить часто виконується апроксимачія вхідних даних, наприклад, тепловиділяючі елементи в збіриі гомогенізуються і геометрично описуються як суцільний чиліндр, час роботи реактора передбачається безперервним при постійній потужності. Ретельність вхідних даних і зроблені припущення залежать від того, яка початкова інформачія доступна та від можливостей комп'ютерної програми. Змодельовані радіаційні параметри відпрацьованого палива залежать не тільки від вихідних даних і припущень, але також від баз даних перерізів, які використовуються в комп'ютерних програмах. Комп'ютерні програми TRITON, ORIGEN-S і FISPACT використовувалися для моделювання концентрації актинідів та продуктів поділу у відпрацьованому паливі реактора РБМК-1000. Отримані результати порівнюються та обговорюються можливі причини розбіжностей в результатах моделювання.

Ключов і слов в: відпрацьоване ядерне паливо, ізотопний склад, контейнер, радіаційна безпека, математичне моделювання. 